\title{
Innovations and Curriculum Development for Technical and Engineering Education in Libya
}

\author{
Nuri M. Triki \\ University of Zawia, Libya
}

\begin{abstract}
Science, technology, engineering development and innovations are the essential key to improvement and are being brought forward at an increasingly rapid rate, thereby forcing engineering educators to adapt to new realities also they play a fundamental role in the creation of wealth, economic development and in the enhancement of the quality of life for all citizens. Furthermore, in the rapidly changing and development in technology and manufacturing industry has affected the national economies and education system of countries and must be continually reevaluated and revised. To make this process more manageable and to create programmes that more accurately reflect the demands of the marketplace, a curriculum revision process is presented. New challenges and new demands are making necessary to re-design curricula of technical and engineering education programmes with industry partnership and business sectors for global economy. The development of curricula should stress the need for flexibility in structure and modes of delivery of technical and engineering education programmes. The curriculum and syllabi in engineering education is dynamic as it shifts with societal requirements as well as student inputs. The paper submits recommendation on further enhanced strategies that will help in the development of education in line with modern trends in curriculum issues. It concludes that for any meaningful advancement to be made in the education sector there must be conscious, deliberate, purposeful, directional policy formulation of the implementation of the curriculum.
\end{abstract}

\section{Introduction}

Engineering education is the activity of teaching engineering and technology, at school, college and university levels. The goal of engineering education is to prepare people to practice engineering as a profession and also to spread technological literacy, increase student interest in technical careers through science and math education and hands-on learning [19].

Engineering is a global industry undergoing a period of unprecedented change. The future of engineering is being framed by global forces which transcend national boundaries such as the impacts of globalisation, rapid technology advances, climate change and inequality. Through the application of science, engineering and humanity has the potential to meet all of its basic needs: water, sanitation, food security, shelter, energy and transport [9].

Technological and scientific advances especially at the interface of advanced computing, biology and physics are leading exponential growth of innovation and opening a world of new possibilities and markets. It follows that engineering higher education needs to constantly strive to keep pace with these advances and in particular the contribution of engineering to these global opportunities and challenges [26].

The $21^{\text {st }}$ Century has introduced many challenges in engineering education. Information technologies hold out the promise of new scientific discoveries, higher standards in communication and increased production, leading to a higher quality of life. The most important challenges to engineering education in the Arab world are the levels of access to information and the quality of education. Problems are currently found in curricula and teaching methods. Lack of access to computers, the internet, and electronic equipment, as well as teaching staff shortages, are the main problems [28].

As in the case with many developed and developing economies, linking technical and engineering education systems with industry is a key priority and often a central principle of policy reform. Additionally, technical and engineering education is one of the key branches of education which produces the manpower resources that make industry more productive [24]. Nevertheless, technical and engineering education plays a substantial role in the social and economic growth of any nation. It serves effectively the needs of the labour market in the country. It is to be noted that many countries have embarked on reforming their technical and engineering education system in terms of structure, management, financing and delivery [30]. Most of the studies that dealt with Libyan socioeconomic issues have mentioned the neglect in 
the area of manpower development in the country, and consequently have emphasised need for technical and engineering education as a key factor to address the most pronounced problem of the shortage of skilled labour [3][2]. Technical and engineering education is therefore considered an essential factor in Libya because the country cannot achieve economic and social development without a skilled, productive workforce that can meet the changing requirements of its environment. Furthermore, a critical issue for the future success of Libyan manufacturing industry is the growth of technical and engineering education in Libya [1].

\section{Curriculum Development}

Curriculum development is the systematic process of designing and preparing all the courses offered in a particular subject [32]. It is one of pedagogical exercises that are necessary for development of education. Its development requires a broader view that considers the needs and the impacts of students, teachers, institutions, employers and governments and includes the factors like content, teaching and evaluation strategies, teaching resources and facilities [26].

[16] refers that, curricula may be organised at two levels. The first approach may be at a macro level, in which the decisions are made about the type of courses to be offered, the amount of time to be devoted to each, the way they will be arranged over the program and so forth. Second, the particular content elements and learning activities can be selected and organised to optimise the knowledge gained by the student. This later approach usually deals with materials within the courses and can be based on principles of teaching and learning and of curriculum design. The two types of organisation may be compared to the adjustment as in tuning a mechanism or an instrument; first gross adjustments are made, and then fine tuning is carried out based on group requirements.

The design of the entire curriculum process is intended to illustrate the syllabus as being the outcome of a complex design activity. This involves the declaration of objectives and simultaneous design of assessment and instruction procedures that will cause those objectives to be obtained for a particular programme and institute [6].

Providers of technical and engineering education should design their curriculum in line with the needs of industry and individual students, and should update the curriculum regularly to accommodate advances in technology, learning and teaching methods, social and cultural development, job market needs and globalisation. Technical and engineering education providers should also design and run short courses for Continued Professional Development (CPD) and life-long learning [29].
According to [18], maintains that curricula design should match the needs of students and cater for their aspirations and requirements. [22], argues that, the importance of considering the workplace as a learning environment for CPD is emphasised, as the tensions arise for learners meeting the demands of academia in full-time employment. Authors in [7], argue that the engineering science curriculum has a significant role in the development of professional engineers. According to [10], the curriculum designer should consult diverse sources that play significant roles in the development of the programme and see the course as part of a whole. It is critical for future economic development that the engineering programmes address the skills needs of the industry and prepare the graduates to play effective roles in their future employment [25].

\section{Higher Education Institutions}

All Higher Education Institutions (HEI) engaged in technical and engineering education need to undertake a review of existing courses to consider the extent to which the global dimension is adequately reflected. However, higher education helps to prepare the professionals who will be responsible for handling markets and industries [17]. Thus, at this level, innovative technologies are needed to meet the requirements of globalisation. The Arab world has tried its best to promote engineering studies. They also tried to develop engineering programmes that can be favourable for women [17]. Technical and engineering education research represents a unique component of education and research. Research in engineering education emphasises not only on research and discovery, but also, reform and implementation. Globally, technical and engineering education research is on the agenda for the improvement of higher engineering education and the development of strategies for solving important issues for the future of engineering education, such as recruitment, the need for new competences and the ability to deal with new types of interdisciplinary and complex knowledge [12].

Curriculum overall can be viewed as a composite whole, including the learner, the teacher, teaching and learning methodologies, anticipated and unanticipated experiences, outputs and outcomes possible within a learning institution. The basic premise is that teachers' professional development is most effective through their active involvement in curriculum design communities [32]. Here teachers are not passively receiving evidence from research and are asked to simply carry out teaching tasks, but they actively apply both research and practical evidence in co-designing curricular products and learning scenarios for their own classrooms [8].

The three components of curriculum innovation can be represented by a triangle of which the design 
approach, teacher development, and participation and collaboration in communities are the three angles (see Figure 1).

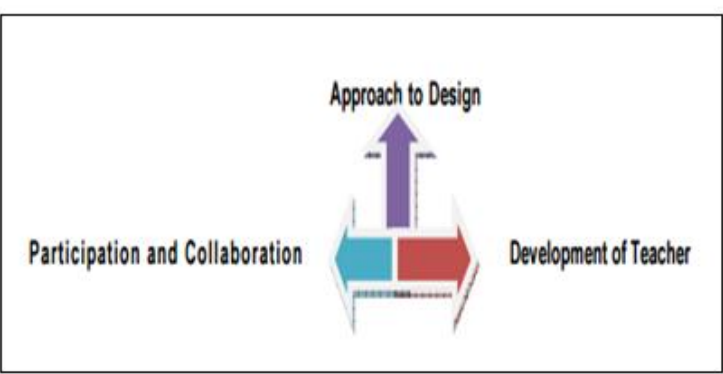

Figure 1. Three components of curriculum innovation

(Source: Parashar, A. and Parashar, R. (2012)

In research, collaboration while designing the curriculum, design communities is approached from two perspectives. The first one is the individual teacher's perspective and the main question is whether collaboration among teachers as design community members, leads to more effective teacher development. Teacher's professional development can be characterised as the gain in pedagogical content knowledge [23].

Four topics are highly relevant is this respect: (i) the process of designing curricular products by teachers; (ii) effects of participation in communities and of collaboration among teachers; (iii) curricular products as the main outcomes of the design process; and (iv) providing computer-based support by external knowledge support and by knowledge produced and communicated by teachers and learners in the design process. The second perspective is the community's perspective and the main question is whether results from curriculum and learning research are best to be implemented through a design project in which teachers take part. Actually research says that the assumption that collaboratively designing by teachers will lead to closing the gap between theory and practice [23].

In the integration of education, research and innovation working together as key drivers of the knowledge economy in delivering sustainable growth [8]. The central research theme is participation and designing by teachers in curriculum design communities and the effectiveness of these factors on teachers' professional development and curriculum innovation in science education. Research shows that curriculum implementation will be positively affected by involving teachers, to varying degrees, in shaping curricular products and learning scenarios in their own classrooms [12]. Further the focus is on empirical and theoretical contributions to foster teachers' professional development and to improve the relation of theory and practice in education, and focus on the practical implementation of these insights in empowering teachers by creating effective design environments in which they can collaboratively design curricular products and learning scenarios for their own classrooms. These are few factors that influence curriculum design viz: (i) political factors, (ii) social factors, (iii) economic factors, (iv) technological factors, (v) environmental factors, (vi) student psychology. Care has to be taken that any curriculum needs to be developed in the light of the organisation or context in which it is going to be delivered [14].

Universities are exploring ways to revise the engineering curriculum in order to meet the changing needs of industry and society. Any restructuring of an engineering curriculum must take into account the correlation between society, engineering competencies and the changing paradigm of engineering education [33]. The 'employability' of graduates depends on a combination of high technical knowledge, practical experience and soft skills. Decreasing student enrolment figures in engineering in many countries call for appropriate measures to be implemented including the development of attractive programmes of study and challenging learning environments. In construction of engineering curriculum three aspects have been neglected: (i) students background in the light of formal and informal experience and interests, (ii) student/student interactions, (iii) teacher/student interaction [33].

According to [20], explore that the innovation of the curriculum with regards to gender mainstreaming means broadly oriented integrated and content rich teaching material, diversity in teaching and learning methods. Since an academic discipline, engineering is continuously undergoing a process of rapid expansion and diversification that is now significantly characterised by interdisciplinary approaches. There is a rise of interest in increasing interdisciplinary studies. As a profession, engineering has to deal with scientific and technological matters, but increasingly economic, political, ethical, societal and environmental aspects are taken into account as well.

Introducing social science and other disciplines into engineering could, ideally, help bridge the rift that exists between producers and consumers of technology. Social sciences, humanities, cultural and management studies are also as important as the traditional applied sciences for the portfolio of engineering competencies because students need to understand the financial, business, environmental, economic and social constraints in which engineers operate [21]. It is seen that problem-based and project based education, which increases the appeal of technical education and have a positive effect on the intake, retention and output of students. Surveys and reports undertaken to document and evaluate active teaching and learning methods indicate that project and problem based learning can satisfy the 
demands for required knowledge, skills and attitudes of engineering graduates [19].

Teachers are the most influential factor in the education change. A curriculum considers the learners and their interaction with each other, the teacher and the materials. Teacher is the most important element in any educational programme. He plays a central role in implementation of educational process at any stage. The level of achievement of learner is determined by teacher competence. So the quality of education basically depends on the quality of teachers [31], [15].

\section{Higher Education in Libya}

To understand Libyan education better, a brief overview on its past provides a comprehensive insight about its education system. Libya became independent on $24^{\text {th }}$ December 1951. Then, the UN clustered Libya as a backward and very poor country with only 15 students graduating in university all with degrees in humanities. A constitutional decree in $11^{\text {th }}$ December 1969 made education free for all. Independence brought rapid changes in the education system and during the 1975-76 academic years, about 13,418 students were studying in university. In 2004, an estimated 200,000 students were studying in Libyan universities with another 70,000 studying in higher technical and vocational education training colleges [11]. To accommodate the rising interest in learning, more institutions of higher learning have been established throughout Libya. The main factor contributing to this high uptake of higher education programs is due to the increased participation of the Libyan government and the free aspect of the education. The higher education system contains a variety of institutions. These include public and private universities, an Open University, technical higher institutions, vocational institutions and also petroleum training and qualifying institutes [5].

The undergraduate higher education system is predominantly financed by the state; students only pay tuition fees at the Open University and private universities. The universities have grown to include several campuses. Undergraduate courses require four to five years' full-time study. Post-graduate studies are not free but are subsidised. Masters studies are of two to three year duration. A Doctorate requires three years of research following completion of a master's degree. Comparatively few students receive Ph.D.s from Libyan universities; mainly in fields such as Arabic, Islamic studies and the humanities. Libyan universities have not yet started doctoral programmes in science, technology, and engineering. Most academics have Doctorate and Masters' degrees from foreign universities [1].

The Open University was established in 1990 in Tripoli and now has 16 campuses around the country. It awards Bachelor's level degrees, depending heavily on printed materials. Higher technical and vocational institutions were established in 1980. These include: higher teacher training institutes; higher vocational centers; and, specialised higher institutes for technical, industrial and agricultural sciences. Higher institutes offer programs in fields such as electricity, mechanical engineering, finance, computer studies, industrial technology, social work, medical technology and civil aviation. After three years study at vocational institutes and centers a Higher Technician Diploma is awarded or else, after four to five years study, the Bachelor's degree is awarded [1], [11].

The government under a public budget programme funds most of the universities. A number of private universities have been accredited to give the Libyan Education system new impetus. The education system in Libya has seen rapid development shape its future. It has significantly improved and advanced compared to other developing countries. The free aspect of it has made more students enrol and take up studies. However, this rapid structural advancement has come with framework pressures that seem to be weighing heavily on it. Socio-cultural issues have also weighed on the system and in the past saw the ban of foreign being imposed barring universities to teach foreign language [27].

\section{Libyan Engineering Education: Achievements and Challenges}

Libya's engineering education has made significant progress in providing engineers and technicians which contributed to building the modern state in Libya. Moreover, engineering education has greatly contributed to the establishment of the concept of citizenship and broadening the Libyan citizen's horizons to the point where the problems of Libya, and the world, are sensed and given due concern [3], [13].

Despite all its achievements, Libyan higher education in general and engineering education in particular still confronts problems, challenges, and criticisms that are precipitated and exacerbated by social and economic circumstances [13]. Libyan universities face challenges to improve the quality of education services, the efficiency of education expenditure and to introduce new teaching and learning methods. These challenges include the provision of better teacher training and qualifications, finding mechanisms for adopting etechnologies, providing professional development and technological infrastructure and overcoming culture influences [3], [27].

The biggest problem facing Libya's higher education in general and engineering education particularly are the quality of its graduates and the lack of conformity of their number and training with 
the requirements of social and economic development and the labour market. This problem complicated further by multiple social factors and pressures, particularly the increasing social demands for university education. In addition, there are no clear assessments of the need for skilled labour. This is combined with surplus of graduates in certain specialisation, such as human sciences, arts, law, and economics, which results in unemployment and acute shortages in other specialties, such as technology. It also leads to the importation of foreign labour in many economic sectors, particularly the oil industry, construction, and high-technology sectors [1], [13].

The relationship between Libyan engineering education and the national development stems from the role played by scientific research in development. It may be said that the relationship between scientific research and the development process is still weak and delicate. Most developmental projects rely on scientific research conducted abroad by international companies and foreign experts. Many industrial projects have been designed and implemented with little or no participation from Libyan experts. This is due to the lack of experience in such fields or to a policy of abdicating responsibility to foreign companies [4],[13]. Nevertheless, most projects take the form of comprehensive contracts and are concluded with little participation from Libyan universities, research centres, and national scientists. Some researchers attributed the weak link between engineering education and development to the following cause factors:

- A shortage of qualified personal who are capable of using modern technologies;

- An insufficient number of specialised institutions which foster research activities and the required updating of technical skills;

- A shortage of information and expertise to facilitate the understanding of what is needed in the technological field to meet national priorities;

- A shortage of expertise in applied field and in the merging of science and technology in the developmental areas of education and industry;

- Insufficient coordination and collaboration between universities and their respective research centres and between governmental institutions and industries;

- Lack of collective work between Libya and other countries, especially Arab countries, with regard to coordinating and managing the process of transferring and using knowledge and technology.

The majority of research conducted by university professors has little to do with local development [13].

\section{Conclusion}

With a global economy that interconnects every country around the world, the demand for qualified professionals' increases. Attracting students into and graduating students from engineering degree programmes is a growing challenge. Evidence is emerging that competence-based teaching, combined with a strong connection to business sectors, can positively impact student academic outcomes. One of the missions of universities and institutions is to guide and promote students professional integration. Thus, formal education programmes should prepare students and train mature workers according to the labour market demands and technological evolution, focusing teaching on competences, in order to face the economic and social challenges ahead. On the other hand, the involvement of enterprises and industry is crucial and should be made in different aspects: curricula design; interchange of students, organisation of study visits and bringing professional to schools; quality assessment and regular feedback.

Thus Libya has developed a national policy for $\mathrm{HE}$ and engineering and scientific research, but these high educational policy needs further development and modernisation in proportion ambitions with economic and social developments in the $21^{\text {st }}$ century.

In summary, curriculum can be designed to facilitate an environment where students discover the power of their own minds to work. Nevertheless, designers are still struggling with the content of curriculum, trying to determine what to put in and what to take out. From my own knowledge and years of experience in university teaching I can attest to the technical and engineering education curriculum being generally very detailed with topics clearly stipulated that must be covered. It is prescriptive curriculum and often the assessments are mandated.

The learning outcomes are structured and developed by academics with no input as such, from industry advisory bodies. Based on the above findings and discussion a number of conclusions can be drawn out

Based on the results and discussion of this study a number of conclusions can be drawn:

- The curriculum in technical and engineering education providers is designed in isolation of stakeholders input and most of the curriculum is imported from other foreign institutions without taking the local needs into account;

- A lack of co-operation between the industry sector concerning technical and engineering education programmes and courses.

- There is lack of effective and efficient planning, implementing and monitoring system. 
- Curriculum is out-dated and did not meet industry needs. No liaison between industry and technical institutes.

- There is lack compulsion of practical work in related industry. No proper weight age to practical work.

- The link between the curriculums of technical and engineering education with the world of work are very weak.

- There is no focus on skill orientated curriculum.

- There is no social adjustment of technologists as compared to conventional graduates.

On the bases of the above discussion and conclusion, the following recommendations can be made:

- Lack of coordination between institutions and world of work hinders job placement of technical graduates. The problem can be addressed by establishing employment centres in the institution to facilitate outgoing graduates. Foreign investment in the local industry can also boost employment opportunities.

- The curricula must therefore be viewed as one of systematically making decisions about the objectives of the educational programmes, content, organisation and methods, and evaluation of the programme outcomes. These decisions will guide and direct the activities of all those who are engaged in the educational enterprise.

- The development of curricula should stress the need for flexibility in structure and modes of delivery of technical and engineering education programmes.

- Present curriculum of technical and engineering education institutions are not at par with the industrial needs and international standards. It is not producing critical thinking skills present curriculum needed to be revised periodically and according to industrial needs.

- Theory and practical work are separately completed, therefore, due to lack of interrelationship between both; their objectives are not achieved so their unification is voice of the present era. There should be more focus on skill orientation in the curriculum. There must be strong relationship between curriculums of technical education with the world of work. The study also recommended introducing semester system in the institutes.

\section{References}

[1] Albadri, A., "Some Problems of Higher Education Policies". Paper Presented in the First National Conference on Public Polices in Libya. Garyounis University, Benghazi, Libya 12-14 June 2007 (Arabic text), 2007.
[2] Aldhaif, R., Murad, O. and Saaod, E., "Higher Engineering Colleges Between Reality and Targets". Proceedings of the Conference on the Development of Engineering and Technical Education in the Beginning of Twenty First Century, Hoon, 30-31 October 2001, 20 pages (Arabic text),2001.

[3] Alfaidy, A. and Ibrahim, M., "Higher Education and Future Challenge in Libya: An Analytical and Critical Prospective". Scientific Garyounis Magazine, Vol. 10, No. 2, pp. 187-211, (Arabic text), 1997.

[4] Alrubaie, K., "Education System and Labour Market Requirements in Libya. Journal of Humanities and Social Sciences, Vol. 15, pp. 1-8, (Arabic text), 2004.

[5] Arabsheibani, G, and Manfor. A., "Non-linearities in Returns to Education in Libya". Education Economics Journal Vol. 9, No. 2pp. 139 -144. 2001.

[6] Barnett, R., "Super Complexity and the Curriculum". Studies in Higher Education, Vol. 25, No. 3, pp. 255- 265. 2000 .

[7] Bohmann, L., Sorby, S. Johnson, D., Mattila, K. and Sutherland, J., "A Model Curriculum for Service Systems Engineering". American Society for Engineering Education. 2007

[8] Borko, H., Flory, M. and Cumbo, K., "Teachers' Ideas and Practices about Assessment and Instruction: A Case Study of the Effects of Alternative Assessment in Instruction, Student learning, and Accountability Practice". CSE Technical Report 366. Los Angeles: Center for Research on Evaluation, Standards, and Student Testing (CRESST). 1993

[9] Blumenthal P. and Grothus, U., "Developing Global Competence in Engineering Students: US and German Approaches". Online Journal for Global Engineering Education, Vol. 3, No. 2, 2008 Article1. http://digitalcommons.uri.edu/ojgee/vol3/iss2/1/ Accessed 22 Aug. 2016

[10] Byers, C., "Defining, Developing, and Implementing a New Design for the Technology Component of a Human Resource Development Undergraduate Programme". Journal of European Industrial Training, Vol. 29 No. 3, pp. 235-245, 2005.

[11] Clark, N., (2004).Education in Libya. World Education News and Reviews, Vol. 17, No. 4. http://www.wes.org/ewenr/04July/Practical.htm Accessed 18 Sep. 2016

[12] Chhokar, K., "Higher Education and Curriculum Innovation for Sustainable Development in India", International Journal of Sustainability in Higher Education, Vol. 11, No. 2, pp. 141-152. 2010

[13] El-Hawat, A., Saeed, B. and Alawami, M., "Higher education in Libya: Achievements and Aspirations". $1^{\text {st }}$ edition. Tripoli: Publications of the Libyan National Committee for Education, Culture and Science Association, and university faculty members in Libya (Arabic text). 2005 
[14] Eli, F. and Quinn, R., "An Experiment to Enhance the Educational Experience of Engineering Students". Engineering Education, Vol. 79, No. 3, pp. 424-429. 1989

[15] Hamid, R., Yusof, M., Osman, S. and Rahmat, R., "Improvement of Delivery Methods in Teaching Materials Technology". WSEAS Transactions on Advances in Engineering Education, Vol. 6, Issue 3, pp.77-86. 2009.

[16] Heywood, J., "Engineering Education: Research and Development in Curriculum and Instruction" WileyInterscience: U.S.A. 2005.

[17] Jones, R. and Oberst, B., "Quality Engineering Education for the Arab States Region". American Society for Engineering Education, 2007.http://www.educationdev. net/edudev/Docs/Q3.pdf Accessed 13 Sep. 2016.

[18] Mbajiorgu, N. and Reid, N., "Factors Affecting Curriculum Development in Chemistry". Higher Education Academy, Hull. 2006

[19] Mills, J. and Treagust, D., "Engineering Education Is Problem-based or Project-based Learning the Answer?" Australasian Journal of Engineering Education, pp. 1-17. The Australasian Association for Engineering Education Inc (AAEE), 2003.

[20] Morris, H. and Glenn, K., "Recent Curriculum Changes in Engineering Science and Mechanics at Virginia Polytechnic Institute and State University". International Journal of Engineering Education, Vol. 16, No. 5, pp. 436-440. 2000

[21] Moubayed, N., Bernard, M. and Jammal, A., “A Survey of Engineering Education in Developing Countries - The Lebanese Case WSEAS Transactions on Advances in Engineering Education, Vol. 6, No. 11, pp. 430-441. 2009 .

[22] Paula, S. and Maire, M., "Work-Based Learning and Continuing Professional Development". Education + Training, Vol. 49, No. 3, PP. 182-192. 2007

[23] Parashar, A. and Parashar, R., "Innovations and Curriculum Development for Engineering Education and Research in India". International Conference on Teaching and Learning in Higher Education (ICTLHE 2012) in conjunction with RCEE \& RHED 2012 Procedia - Social and Behavioral Sciences 56 ( 2012 ) 685 - 690.

[24] Ravinder, R. and Kahsu, B., "Labour Market Needs and Development of Technical and Vocational Education in Eritrea". New Delhi (India): Manpower Journal, Vol. 41, pp. 4. 2006

[25] Raide'n, A. and Dainty, A., "Human Resource Development in Construction Organisations an Eexample of a "chaordic" Learning Organisation?" The Learning Organisation, Vol. 13 No. 1, pp. 63-79. 2006

[26] Saha, S., "Curriculum Design of Mechanical Engineering in a Developing Country". 3rd International Symposium for Engineering Education, 2010, University College Cork, Ireland
[27] Tamtam, A., Gallagher F., Olabi, A. and Naher S., "Higher Education in Libya, System Under Stress" International Conference on Education and Educational Psychology (ICEEPSY 2011) Procedia - Social and Behavioral Sciences 29 (2011) 742 - 751. 2011

[28] Tamtam, A., Gallagher F., Naher S. and Olabi, A., "EMI for Engineering Education in Arab World and Twenty First Century Challenges". 3rd International Symposium for Engineering Education, 2010, University College Cork, Ireland. 2010

[29] Triki, N., Gupta, N., Rafik, T. and Wamuziri, S., "A Survey on the Effectiveness of the Curriculum for the Libyan Manufacturing Industry". International Conference on Engineering Education and International Conference on Engineering Education and Research (ICEE \& ICEER KOREA 2009), 23-28August, 2009 Seoul, Korea.

[30] Twati, J., Gammack,J., "The Impact of Organisational Culture Innovation on the Adoption of IS/IT: the Case of Libya". Journal of Enterprise Information Management, Vol. 19, No. 2, pp.175-191. 2006

[31] Tiwari M., "Teacher Education: Problems and Suggestions". International Journal of Multidisciplinary Education and Research, Vol. 1, No. 1, pp. 28-30. 2016.

[32] Walkington, J., "Curriculum Change in Engineering". European Journal of Engineering Education, Vol. 27, No. 2, pp. $133-148.2002$

[33] Yeomans, R. and Atrens, A., "A methodology for Discipline-specific Curriculum Development". International Journal of Engineering Education, Vol. 17, No. 6, pp. 518-524. 2001 